ASTHMA

\title{
The early origins hypothesis with an emphasis on growth rate in the first year of life and asthma: a prospective study in Chile
}

\author{
R J Rona, N C Smeeton, P Bustos, H Amigo, P V Diaz
}

Thorax 2005;60:549-554. doi: 10.1136/thx.2004.032359

See end of article for authors' affiliations

....................

Correspondence to: Professor R J Rona Department of Public Health Sciences, King's College London, 5th Floor, Capital House, 42 Weston Street, London SE 1 3QD, UK; roberto.rona@kcl.ac. uk

Received 30 July 2004 Accepted

20 February 2005

\begin{abstract}
Background: There is uncertainty about the impact of the programming hypothesis in terms of nutritional status at birth, rate of growth in the first year of life, length of gestation, breast feeding, and episodes of illness on asthma. An analysis was therefore carried out to test this hypothesis.

Methods: Data were collected on 1232 children born between 1974 and 1978 in a semi-rural area of Chile. Measurements at birth and growth in the first year of life were obtained from a birth registry and clinical notes. Information on asthma was collected using the European Community Respiratory Health Survey questionnaire. Sensitisation to eight allergens and bronchial hyperresponsiveness (BHR) to methacholine were determined. All other information was obtained using a questionnaire. Polytomous logistic analyses were carried out to explore the association of factors at birth and during the first year of life with asthma symptoms, atopy, and BHR.

Results: Weight and length gain in the first year were positively associated with wheeze (odds ratio (OR) $1.004,95 \% \mathrm{Cl} 1.001$ to 1.007 and OR $1.11,95 \% \mathrm{Cl} 0.98$ to 1.25 , respectively). A higher body mass index (BMI) at birth was protective in subjects reporting both wheeze and waking with breathlessness (OR $0.54,95 \% \mathrm{Cl} 0.35$ to 0.84 ). Length rate in tertiles divided by length at birth in tertiles was related to asthma symptoms (OR $1.68,95 \% \mathrm{Cl} 1.19$ to 2.37 ). Most other assessments were not associated with asthma.

Conclusion: These results show promising but inconclusive evidence that a rapid rate of growth in length, especially in newborn infants of low length, might be involved in the aetiology of asthma.
\end{abstract}

S usceptibility to asthma and poor lung function have been linked to events and processes in newborn infants and the first year of life. Although there is consistency in several studies on the positive association between birth weight and lung function, there is less agreement on the association between birth weight and asthma. ${ }^{1-10}$ Some studies have shown a negative association, ${ }^{156}$ while others have shown no association ${ }^{39}$ or a positive association. ${ }^{10}$ Studies have also reported a similar type of association between asthma in relation to gestational age, ${ }^{311}{ }^{12}$ breast feeding,,$^{13}{ }^{14}$ and infections ${ }^{915}$ in the first year of life, but all these associations have been contested. ${ }^{16-18}$ The published results are not consistent, and the fact that the majority of papers have reported positive results may have been due to publication bias or researchers submitting papers only on those analyses showing a significant association. Lack of consistency has also characterised analysis of head circumference at birth in relation to IgE and asthma. ${ }^{19-23}$

With one exception, ${ }^{4}$ most studies have been based in developed countries and the findings may not correspond to those from less economically developed countries. One of the main issues of programming is related to undernutrition and poor environmental circumstances in the mother, the fetus, and the infant. It would therefore be more relevant to investigate this hypothesis with data from appropriate settings.

We studied asthma symptoms, sensitisation, and bronchial hyperresponsiveness (BHR) to methacholine in a population of young adults in a semi-rural area in Chile. We also had access to information about birth weight, length at birth, duration of breast feeding, infections in the first year of life, and rate of growth and body mass index (BMI) in the first year of life. Our aim was to assess the whole range of early life variables as possible causal factors of asthma. We were especially interested in assessing the association between growth in the first year and asthma. This has not been reported previously since it is unusual to have this type of information in a large data set.

\section{METHODS \\ Sample}

This was a non-concurrent prospective study as the survey was carried out between January 2001 and April 2003, and additional information collected at birth and in the first year of life was available in a registry and clinical notes. A sampling frame based on all births in the Hospital of Limache in Chile between 1974 and 1978 ( 5 years) was used for randomly selecting 1232 subjects. Those who could not be included in the study because of death (3.2\%), emigration $(11.3 \%)$, excluding reasons such as custodial sentence, disability or lactation (3.3\%) and unwillingness to participate $(7 \%)$ were randomly replaced using the same sampling frame. This strategy ensured that those participating in the survey would have information recorded at birth and were likely to have clinical information regarding the first year of life.

Limache is an agricultural area of approximately 50000 inhabitants. Many of its products are exported but, despite its favourable economic position, poverty breeding corresponds to the median for Chile. ${ }^{24}{ }^{25}$ We chose Limache for our study because of the high quality birth and medical records in the first year of life and the low emigration rates in this population.

The ethics committee of the Faculty of Medicine of the University of Chile approved the study. 


\section{Assessments}

Participants completed the Spanish version of the European Community Respiratory Health Survey (ECRHS) questionnaire adapted for use in Chile. ${ }^{26}$ Skin test sensitisations to cat fur, dog hair, cockroach, Dermatophagoides pteronyssinus, Alternaria alternata, and blends of grass pollens, trees, and weeds and shrubs common in Chile were assessed (samples obtained from Allergy Therapeutics). A weal size of at least $3 \mathrm{~mm}$ was considered positive in this analysis and this was unadjusted for histamine control following advice. ${ }^{27}$ BHR challenge to methacholine was assessed using the tidal breathing methodology. ${ }^{28}$ Increasing concentrations of 0.5 , $1.00,4.00,8.00$ and $16 \mathrm{mg} / \mathrm{ml}$ were used with a Hudson nebuliser at a flow rate of $0.13 \mathrm{l} / \mathrm{min}$ over a period of 2 minutes. Forced expiratory volume in 1 second $\left(\mathrm{FEV}_{1}\right)$ was measured using a Vitalograph 2120 and software Spirotrac IV following the American Thoracic Society (ATS) norms. ${ }^{29} \mathrm{~A}$ decrease in $\mathrm{FEV}_{1}$ of $20 \%$ compared with baseline $\mathrm{FEV}_{1}$ at any concentration up to $16 \mathrm{mg} / \mathrm{ml}\left(\mathrm{PC}_{20}\right)$ was considered a positive BHR. Participants were advised not to smoke or take asthma relievers and preventives before the test for at least 1 and 6 hours, respectively. Subjects with an expected FEV below $70 \%$ of the predicted value and those with a heart condition, epilepsy, current pregnancy, or who were breast feeding were excluded. The tests and measurements were carried out in a health setting with ready access to medical facilities. Three university nurses trained for the study administered the questionnaire and carried out the tests.

Information was also collected on current smoking, number of household possessions, car ownership, and number of brothers and sisters. The possessions included were a gas fuelled water heating device, refrigerator, washing machine, and microwave oven. BMI was calculated based on height and weight measurements. The issue of parental asthma was not covered in the questionnaire.

The information collected from the birth registry and clinical notes in the first year of life were birth weight, length at birth, length of pregnancy, and duration of breast feeding. Weight and length at the age of 12 months were used and, if unavailable, measurements taken at 10 or 11 months were used and corrected to age 12 months using UK reference values. $^{30}$ Midwives measured weight and length at birth following norms published by the Ministry of Health in 1973. The norms describe the equipment and advise staff to adjust for the weight of any garment put on the scales to protect the baby. The measurement techniques were illustrated and summarily explained. Gestational age was estimated from the first day of last normal menstruation period (LNMP). We calculated BMI at birth and at 1 year.

\section{Statistical analysis}

The main analyses were carried out using polytomous logistic regression. ${ }^{31}$ This method is an extension of multiple logistic regression and allows the dependent variable to have more than two categories. The rationale for using this method was that, for subjects with a manifestation of asthma, those with only a single asthma symptom need to be considered separately from those who have asthma symptoms, positive BHR, and sensitisation to at least one tested allergen. The polytomous logistic regression method allowed us to combine two characteristics (for example, asthma symptoms and positive BHR) to assess associations with the independent variables for each characteristic separately and together. Three main polytomous analyses were carried out: one in which the characteristics representing asthma symptoms were wheeze in the last 12 months and waking with breathlessness at night in the last 12 months (the two were chosen a priori as asthma symptoms in the analysis); another in which wheeze or waking with breathlessness at night in
Table 1 Prevalence of each dependent variable and some independent factors in the analysis

\begin{tabular}{|c|c|c|}
\hline Variable & $\begin{array}{l}\text { Men } \\
(N=556)\end{array}$ & $\begin{array}{l}\text { Women } \\
(N=676)\end{array}$ \\
\hline Wheeze in last 12 months & $147(26.4 \%)$ & $189(28.0 \%)$ \\
\hline $\begin{array}{l}\text { Woken by breathlessness in } \\
\text { last } 12 \text { months }\end{array}$ & $58(10.4 \%)$ & $111(16.4 \%)$ \\
\hline Positive BHR & $45(8.1 \%)$ & $111(16.4 \%)$ \\
\hline Atopic to at least 1 allergen & $159(28.6 \%)$ & $186(27.5 \%)$ \\
\hline \multicolumn{3}{|l|}{ Duration of breast feeding } \\
\hline Did not breast feed & $10(1.8 \%)$ & $21(3.1 \%)$ \\
\hline$<1$ month & $206(37.1 \%)$ & $221(32.7 \%)$ \\
\hline$\geqslant 1$ month & $287(51.6 \%)$ & $353(52.2 \%)$ \\
\hline Not known & $53(9.5 \%)$ & $81(12.0 \%)$ \\
\hline Current smokers & $379(68.2 \%)$ & $344(50.9 \%)$ \\
\hline \multicolumn{3}{|l|}{ No of possessions* } \\
\hline 0 or 1 & $76(13.7 \%)$ & 101 (14.9\%) \\
\hline 2 & $174(31.4 \%)$ & $240(35.5 \%)$ \\
\hline 3 or 4 & $305(55.0 \%)$ & $335(49.6 \%)$ \\
\hline \multicolumn{3}{|l|}{ No of siblings } \\
\hline 0 or 1 & $77(13.9 \%)$ & $90(13.4 \%)$ \\
\hline 2 or 3 & $242(43.6 \%)$ & $281(41.8 \%)$ \\
\hline$\geqslant 4$ & $236(42.5 \%)$ & $301(44.8 \%)$ \\
\hline \multicolumn{3}{|c|}{$\begin{array}{l}\text { BHR, bronchial hyperresponsiveness; BMI, body mass index; FEV } 1 \text {, } \\
\text { forced expiratory volume in } 1 \text { second. } \\
\text { *Microwave oven, gas fuelled water heater device, washing machine, } \\
\text { refriaerator }\end{array}$} \\
\hline
\end{tabular}

the last 12 months and positive atopy or BHR were combined; and a third in which atopy and BHR were considered together. This approach covered all possible combinations of asthma symptoms, positive BHR, and sensitisation. This allowed us to determine whether an association was statistically significant for participants with a specific characteristic only or whether it was consistent across the spectrum of asthma. In the first column of results in the tables, individuals positive on one of the characteristics considered are compared with those who are negative on both. The second column relates similarly to the other characteristic. In the third column, individuals positive to the two characteristics are compared with those negative on both. We used as independent variables those described above, apart from respiratory and gastrointestinal episodes of disease in the first year. As height and weight at birth are highly associated, we carried out separate analyses for these two variables. The results in which birth weight and weight gain in the first year of life were included as independent factors are shown in the tables. We adjusted the association of early life variables and the polytomous dependent variables for sex, the socioeconomic factors explained above, current smoking, adult BMI, and number of sisters and brothers. The analysis was performed using the mlogit command in Stata Version 8.0 (Stata Corporation, College Station, TX, USA, 2003).

We also examined the hypothesis that the combination of low birth weight and rapid increase in weight in the first year may be related to asthma. The length of the baby was examined in the same way. Ratios of the tertile of the rate of increase in weight divided by the tertile of birth weight (weight ratio) and tertile of the rate of increase in length ratio divided by the tertile of birth length (length ratio) were used in separate analyses. Thus, an infant could fall into one of three categories of length or weight in the first year of life and one of three categories of weight or length at birth.

As there was incomplete information on duration of breast feeding and length of pregnancy, these two variables were included in the analyses as categorical variables which included a "not known" group. Breast feeding was dichotomised using a cut off point of 1 month. This unconventional approach was taken because very few women did not breast feed for at least 1 week. Rate of growth up to the age of 
Table 2 Mean (SD) anthropometric and lung function characteristics of the sample

\begin{tabular}{lll}
\hline & Men & Women \\
\hline Birth weight $(\mathrm{g})$ & $3226(491), \mathrm{n}=554$ & $3160(503), \mathrm{n}=675$ \\
Length at birth $(\mathrm{cm})$ & $49.69(2.06), \mathrm{n}=554$ & $49.29(2.16), \mathrm{n}=671$ \\
BMl at birth $\left(\mathrm{kg} / \mathrm{m}^{2}\right)$ & $13.00(1.34), \mathrm{n}=554$ & $12.97(1.41), \mathrm{n}=671$ \\
Height at 12 months $(\mathrm{cm})$ & $73.16(3.18), \mathrm{n}=477$ & $71.75(2.85), \mathrm{n}=599$ \\
Weight at 12 months $(\mathrm{kg})$ & $9.71(1.26), \mathrm{n}=536$ & $9.14(1.12), \mathrm{n}=648$ \\
BMl at 12 months $\left(\mathrm{kg} / \mathrm{m}^{2}\right)$ & $18.09(1.63), \mathrm{n}=477$ & $17.75(1.74), \mathrm{n}=599$ \\
Adult height $(\mathrm{cm})$ & $168.2(6.0), \mathrm{n}=556$ & $156.3(5.5), \mathrm{n}=676$ \\
Adult BMI $\left(\mathrm{kg} / \mathrm{m}^{2}\right)$ & $25.20(3.60), \mathrm{n}=556$ & $26.00(4.81), \mathrm{n}=676$ \\
FEV & $4.12(0.53), \mathrm{n}=554$ & $3.09(0.38), \mathrm{n}=6722$ \\
\hline BMl, body mass index; FEV &
\end{tabular}

12 months was available or could be estimated from information at $10-11$ months for $1062(86 \%)$ of the 1232 participants. Data on all remaining variables were complete, except in 19 individuals who were excluded from the analyses.

\section{RESULTS}

Respiratory symptoms such as wheeze in the last 12 months and waking at night with breathlessness in the last 12 months were highly prevalent (table 1). BHR and being woken by breathlessness in the last 12 months were more prevalent in women than men. Approximately 10\% of the newborns had a gestation period of less than 37 weeks; most babies were breast fed, over half for more than 1 month. A very high percentage of participants were current smokers, were from a large sibship, and their poverty level (judged by the number of household possessions) corresponded to an average population by Chilean standards. Women were shorter and lighter than men at birth and at 1 year of age (table 2). Compared with UK reference values, men were $250 \mathrm{~g}$ lighter at birth and $400 \mathrm{~g}$ lighter at 1 year and women were $130 \mathrm{~g}$ lighter at birth and $430 \mathrm{~g}$ at 1 year. ${ }^{30}$ Their adult BMI was high with means of 25.2 and 26.0 in men and women respectively, but their final height was low compared with Western values.

Table 3 shows the separate and joint odds ratios (ORs) of wheeze in the last 12 months and waking with breathlessness at night in the last 12 months with the independent variables. Of all the variables related to birth and the infant period of life, only weight gain in the first year was positively associated with wheeze in the last 12 months $(\mathrm{p}=0.011)$.
The two asthma symptoms together were negatively associated with BMI at birth $(p=0.007)$. Those who were breast fed for less than a month were less likely to have wheeze than those breast fed for longer than a month $(p=0.023)$. More women than men woke with breathlessness at night $(p=0.01)$. Current smoking status was associated with wheeze and the two symptoms combined $(\mathrm{p}<0.001$ and 0.009 , respectively). Car ownership was associated with a reduced risk of the combined symptoms $(p=0.025)$. The replacement of weight and weight gain for length and length rate in the analysis did not change the results (not shown). Length rate was associated with wheeze $(p=0.009)$. When we excluded the growth gain in the first year to enable a similar analysis in the total sample, the association between BMI at birth and wheeze disappeared and adult BMI and wheeze reached the conventional level of statistical significance $(\mathrm{p}=0.048)$.

Length ratio was significantly associated with wheeze in the last 12 months in the polytomous analysis (OR 1.68 (95\% CI 1.19 to 2.37 ), $p=0.003$; table 4 ). The length ratio variable markedly reduced the association between length rate and wheeze, indicating that the combination of length rate tertiles divided by length birth weight tertiles was more important than length rate on its own. Length ratio was also associated with the two asthma symptoms together, albeit not reaching the conventional significance level $(p=0.093)$. Length at birth was associated with both symptoms together $(p=0.017)$. Length ratio was also found significantly associated with wheeze in the last 12 months or waking with breathlessness in the last 12 months (OR 1.74 (95\% CI 1.21 to 2.50$), \mathrm{p}=0.003$; not shown).

Table 3 Association between variables at birth, first year of life, socioeconomic factors and smoking and wheeze and waking with breathlessness at night by polytomous regression analysis $(n=1062)^{*}$

\begin{tabular}{|c|c|c|c|}
\hline & $\begin{array}{l}\text { Wheezet } \\
\text { OR }(95 \% \mathrm{Cl}) \text {, p value }\end{array}$ & $\begin{array}{l}\text { Waking with breathlessness } t \\
\text { OR }(95 \% \mathrm{Cl}) \text {, p value }\end{array}$ & $\begin{array}{l}\text { Two symptoms combined } \\
\text { OR }(95 \% \mathrm{CI}) \text {, p value }\end{array}$ \\
\hline Sex (female) & $1.25(0.89$ to 1.75$), 0.191$ & $2.10(1.20$ to 3.71$), 0.010$ & $1.61(0.93$ to 2.77$), 0.087$ \\
\hline No of siblings & $0.99(0.91$ to 1.07$), 0.755$ & $1.05(0.94$ to 1.17$), 0.407$ & $1.12(1.00$ to 1.24$), 0.044$ \\
\hline Birth weight $(100 \mathrm{~g})$ & $0.95(0.89$ to 1.01$), 0.110$ & $0.94(0.85$ to 1.05$), 0.282$ & $1.08(0.97$ to 1.21$), 0.158$ \\
\hline Weight gain in first year $(\mathrm{g} / \mathrm{month})$ & $1.004(1.001$ to 1.007$), 0.011$ & $1.001(0.996$ to 1.006$), 0.690$ & $1.004(0.999$ to 1.008$), 0.141$ \\
\hline BMl at birth $\left(\mathrm{kg} / \mathrm{m}^{2}\right)$ & $1.02(0.78$ to 1.32$), 0.888$ & $0.87(0.58$ to 1.31$), 0.501$ & $0.54(0.35$ to 0.84$), 0.007$ \\
\hline BMI gain in first year $\left(\mathrm{kg} /\left(\mathrm{m}^{2}\right.\right.$ month)) & $0.20(0.03$ to 1.40$), 0.105$ & $0.20(0.01$ to 4.74$), 0.318$ & $0.18(0.01$ to 4.34$), 0.290$ \\
\hline Smoking status & $2.24(1.59$ to 3.16$),<0.001$ & $1.27(0.76$ to 2.10$), 0.358$ & 2.07 (1.20 to 3.56$), 0.009$ \\
\hline Car ownership & $1.00(0.69$ to 1.44$), 0.988$ & $0.74(0.39$ to 1.38$), 0.336$ & $0.43(0.20$ to 0.90$), 0.025$ \\
\hline \multicolumn{4}{|l|}{ Length of pregnancy } \\
\hline$<37$ weeks & $0.71(0.41$ to 1.25$), 0.241$ & $0.55(0.22$ to 1.41$), 0.215$ & $0.57(0.22$ to 1.45$), 0.238$ \\
\hline Not known & $0.77(0.54$ to 1.09$), 0.140$ & $0.70(0.40$ to 1.22$), 0.206$ & $0.83(0.48$ to 1.44$), 0.509$ \\
\hline \multicolumn{4}{|l|}{ Duration of breast feeding } \\
\hline$\leqslant 1$ month & $0.64(0.43$ to 0.94$), 0.023$ & $0.58(0.31$ to 1.09$), 0.088$ & $0.94(0.52$ to 1.70$), 0.834$ \\
\hline Not known & $0.86(0.49$ to 1.49$), 0.583$ & $1.03(0.46$ to 2.30$), 0.938$ & $1.68(0.81$ to 3.52$), 0.166$ \\
\hline No of household belongings & $0.94(0.79$ to 1.12$), 0.469$ & $0.98(0.75$ to 1.29$), 0.904$ & $0.86(0.66$ to 1.13$), 0.280$ \\
\hline Adult BMI $\left(\mathrm{kg} / \mathrm{m}^{2}\right)$ & 1.03 (0.99 to 1.06 ), 0.169 & $1.04(0.98$ to 1.10$), 0.175$ & $1.04(0.98$ to 1.10$), 0.221$ \\
\hline \multicolumn{4}{|c|}{$\begin{array}{l}\text { OR, odds ratio; BMI, body mass index. } \\
\text { *Each assessment was adjusted for all the variables in the table. } \\
\text { †Asthma symptoms in the last } 12 \text { months. }\end{array}$} \\
\hline
\end{tabular}


Table 4 Association between length at birth, length rate, and length ratio and wheeze and waking with breathlessness at night by polytomous regression analysis $(n=1062)^{*}$

\begin{tabular}{|c|c|c|c|}
\hline & $\begin{array}{l}\text { Wheeze } † \\
\text { OR }(95 \% \mathrm{CI}) \text {, p value }\end{array}$ & $\begin{array}{l}\text { Waking with breathlessness } \\
\text { OR }(95 \% \mathrm{Cl}) \text {, p value }\end{array}$ & $\begin{array}{l}\text { Two symptoms combined } \\
\text { OR }(95 \% \mathrm{Cl}), \mathrm{p} \text { value }\end{array}$ \\
\hline Length at birth $(\mathrm{cm})$ & 1.11 (0.98 to 1.25$), 0.096$ & $1.00(0.83$ to 1.21$), 0.984$ & $1.27(1.04$ to 1.55$), 0.017$ \\
\hline Length rate $(\mathrm{cm} /$ month) & $1.16(0.45$ to 2.97$), 0.753$ & $0.76(0.16$ to 3.57$), 0.729$ & $1.13(0.24$ to 5.36$), 0.871$ \\
\hline $\begin{array}{l}\text { Length ratio (tertile length rate/tertile } \\
\text { length at birth) }\end{array}$ & 1.68 (1.19 to 2.37$), 0.003$ & $1.33(0.77$ to 2.28$), 0.303$ & 1.61 (0.92 to 2.81$), 0.093$ \\
\hline
\end{tabular}

OR, odds ratio; BMI, body mass index.

*Each assessment was adjusted for sex, number of siblings, current smoking behaviour, socioeconomic level, BMl at birth, BMI rate, and the other variables in the table.

†Asthma symptoms in the last 12 months.

We looked at the associations between all the main components of asthma (asthma symptoms, atopy and BHR status) in one polytomous analysis (table 5). In such an analysis the two dependent variables were asthma symptoms, wheeze in the last 12 months or waking with breathlessness at night in the last 12 months, and atopy or BHR. Weight and BMI at birth were unrelated to the dependent variables. An unknown length of pregnancy was negatively associated with asthma symptoms and a short length of pregnancy was protective of having the two variables together. Smoking was highly associated with asthma symptoms and the two dependent variables together $(\mathrm{p}<0.001)$ and adult BMI was associated with asthma symptoms $(p=0.023)$. In the analysis in which length at birth replaced birth weight, the results were broadly similar. Length and weight gain in the analysis including only 1062 participants was positively associated with asthma symptoms $(p=0.034$ and $\mathrm{p}=0.031$, respectively).

In a separate polytomous analysis we looked at the association between the more objective components of asthma-atopy to at least one allergen and BHR. None of the variables reflecting newborn and infant characteristics were associated with atopy or BHR, but those with a short length of pregnancy were less likely to have atopy, although the association did not reach the conventional significance level of $\mathrm{p}<0.05$ (table 6 ). BHR was more prevalent in women, smokers, in those not owning a car, and in those with a low BMI. Some evidence was found that sibship was negatively associated with atopy and with BHR and atopy together. In the separate analysis with the reduced sample, weight and height gain in the first year were not associated with atopy or BHR.

There was a borderline insignificant association between length ratio and sensitisation $(p=0.086)$ in the unadjusted model which was not apparent after adjustment $(p=0.163)$. Infants with low length at birth but rapid growth tended to have a higher level of sensitisation. We did not find an association between the weight ratio and any dependent variables.

Analysis in relation to number of episodes of respiratory infections and diarrhoea in the first year and the dependent variables asthma symptoms, atopy, and BHR were all not significant (not shown). Anthropometric measurements at birth and during the first year of life were unrelated to $\mathrm{FEV}_{1}$.

\section{DISCUSSION}

There was some evidence that weight and length gain in the first year and BMI at birth were positively associated with wheeze in the last 12 months, and that the length ratio was positively related to wheeze in the last 12 months and waking with breathlessness in the last 12 months. We found little or no evidence that the other variables during the first year of life-such as breast feeding, length of pregnancy, diarrhoea and respiratory infections-were associated with asthma symptoms, sensitisation, and BHR.

\section{Strengths and weaknesses of the study}

Our results are important because we had information at birth and during the first year of life recorded at the time these events occurred, and the study was carried out in a sample born when infant malnutrition was prevalent in Chile. We are the first group to report on the rate of growth in the first year of life in relation to asthma. The data corresponding to the adult period are of high quality and are complete as the questionnaires were administered and trained fieldworkers carried out the assessments. Our strategy of analysis was to include all the independent variables, thus avoiding bias by choosing solely independent

Table 5 Association between variables at birth, socioeconomic factors, and smoking and asthma symptoms (wheeze or waking with breathlessness), BHR, and atopy by polytomous regression analysis $(n=1213)$ *

\begin{tabular}{|c|c|c|c|}
\hline & $\begin{array}{l}\text { Asthma symptoms in last } 12 \text { months } \\
\text { OR }(95 \% \mathrm{Cl}) \text {, p value }\end{array}$ & $\begin{array}{l}\text { Atopy or positive BHR } \\
\text { OR }(95 \% \mathrm{CI}), \mathrm{p} \text { value }\end{array}$ & $\begin{array}{l}\text { Two characteristics combined } \\
\text { OR }(95 \% \mathrm{Cl}) \text {, p value }\end{array}$ \\
\hline Sex (female) & $1.54(1.11$ to 2.13$), 0.009$ & $1.33(0.97$ to 1.81$), 0.073$ & $1.36(0.95$ to 1.95$), 0.090$ \\
\hline No of siblings & $1.02(0.95$ to 1.09$), 0.604$ & $0.94(0.88$ to 1.01$), 0.108$ & $0.96(0.88$ to 1.03$), 0.266$ \\
\hline Birth weight (100 g) & $0.97(0.91$ to 1.03$), 0.307$ & $1.01(0.94$ to 1.07$), 0.873$ & $0.99(0.92$ to 1.07$), 0.790$ \\
\hline BMI at birth $\left(\mathrm{kg} / \mathrm{m}^{2}\right)$ & $0.98(0.78$ to 1.23$), 0.843$ & $1.02(0.82$ to 1.28$), 0.838$ & $0.97(0.75$ to 1.26$), 0.814$ \\
\hline Smoking status & $2.03(1.46$ to 2.83$),<0.001$ & $1.18(0.87$ to 1.61$), 0.279$ & $1.98(1.37$ to 2.87$),<0.001$ \\
\hline Car ownership & $0.95(0.66$ to 1.38$), 0.803$ & $0.92(0.65$ to 1.30$), 0.625$ & $0.71(0.47$ to 1.09$), 0.122$ \\
\hline \multicolumn{4}{|l|}{ Length of pregnancy } \\
\hline$<37$ weeks & $0.88(0.52$ to 1.48$), 0.631$ & $1.12(0.68$ to 1.85$), 0.661$ & $0.35(0.16$ to 0.78$), 0.010$ \\
\hline Not known & 0.65 (0.46 to 0.93$), 0.019$ & $0.97(0.70$ to 1.35$), 0.859$ & $0.93(0.64$ to 1.35$), 0.703$ \\
\hline \multicolumn{4}{|l|}{ Duration of breast feeding } \\
\hline$\leqslant 1$ month & $0.66(0.45$ to 0.97$), 0.036$ & $1.00(0.71$ to 1.41$), 0.991$ & $0.71(0.47$ to 1.07$), 0.105$ \\
\hline Not known & $1.18(0.72$ to 1.94$), 0.507$ & $1.04(0.63$ to 1.73$), 0.864$ & 0.95 (0.54 to 1.68$), 0.859$ \\
\hline No of household belongings & $0.93(0.79$ to 1.11$), 0.438$ & $1.00(0.85$ to 1.19$), 0.972$ & 0.88 (0.73 to 1.07$), 0.196$ \\
\hline Adult BMI $\left(\mathrm{kg} / \mathrm{m}^{2}\right)$ & $1.04(1.01$ to 1.08$), 0.023$ & $1.00(0.97$ to 1.04$), 0.872$ & $1.03(0.99$ to 1.07$), 0.195$ \\
\hline
\end{tabular}


Table 6 Association between variables at birth, socioeconomic factors, and smoking and BHR and atopy by polytomous regression analysis $(n=1213)^{*}$

\begin{tabular}{|c|c|c|c|}
\hline & $\begin{array}{l}\text { Atopy } \\
\text { OR }(95 \% \mathrm{Cl}) \text {, p value }\end{array}$ & $\begin{array}{l}\text { Positive BHR } \\
\text { OR }(95 \% \mathrm{Cl}) \text {, p value }\end{array}$ & $\begin{array}{l}\text { Atopy and positive BHR combined } \\
\text { OR }(95 \% \mathrm{Cl}) \text {, p value }\end{array}$ \\
\hline Sex (females) & $0.82(0.61$ to 1.09$), 0.162$ & 2.01 (1.25 to 3.23 ), 0.004 & $3.01(1.63$ to 5.54$),<0.001$ \\
\hline No of siblings & 0.95 (0.89 to 1.01$), 0.099$ & 0.98 (0.89 to 1.08$), 0.621$ & 0.88 (0.77 to 1.01$), 0.066$ \\
\hline Birth weight $(100 \mathrm{~g})$ & 1.02 (0.96 to 1.08$), 0.559$ & $1.03(0.94$ to 1.13$), 0.476$ & $0.94(0.85$ to 1.05$), 0.267$ \\
\hline BMl at birth $\left(\mathrm{kg} / \mathrm{m}^{2}\right)$ & $1.03(0.83$ to 1.27$), 0.796$ & 0.95 (0.68 to 1.32$), 0.759$ & $1.02(0.70$ to 1.47$), 0.921$ \\
\hline Smoking status & $1.06(0.80$ to 1.41$), 0.684$ & 1.59 (0.99 to 2.54$), 0.053$ & $1.26(0.74$ to 2.14$), 0.404$ \\
\hline Car ownership & 1.01 (0.73 to 1.39 ), 0.965 & $0.45(0.24$ to 0.84$), 0.011$ & $0.76(0.40$ to 1.44$), 0.394$ \\
\hline \multicolumn{4}{|l|}{ Length of pregnancy } \\
\hline$<37$ weeks & $0.62(0.36$ to 1.08$), 0.091$ & $1.24(0.61$ to 2.51$), 0.551$ & 0.91 (0.39 to 2.13$), 0.825$ \\
\hline Not known & $1.13(0.84$ to 1.52$), 0.428$ & $0.93(0.56$ to 1.53$), 0.764$ & $1.09(0.61$ to 1.94$), 0.781$ \\
\hline \multicolumn{4}{|l|}{ Duration of breast feeding } \\
\hline$\leqslant 1$ month & $0.98(0.70$ to 1.35$), 0.883$ & $0.80(0.46$ to 1.39$), 0.428$ & $1.29(0.73$ to 2.28$), 0.385$ \\
\hline Not known & $0.87(0.55$ to 1.40$), 0.575$ & 1.33 (0.70 to 2.52$), 0.381$ & $0.79(0.30$ to 2.07$), 0.625$ \\
\hline No of household belongings & 0.95 (0.81 to 1.10$), 0.478$ & $0.99(0.78$ to 1.26$), 0.961$ & 1.03 (0.77 to 1.38 ), 0.845 \\
\hline Adult BMI $\left(\mathrm{kg} / \mathrm{m}^{2}\right)$ & 1.03 (1.00 to 1.06$), 0.094$ & 0.94 (0.89 to 0.99$), 0.028$ & 0.96 (0.90 to 1.02$), 0.161$ \\
\hline
\end{tabular}

variables most likely to show a positive association with asthma. We used current measures of socioeconomic status as we believe it is more reliable, but in our data parental education level was associated with the participant's education level. The weaknesses of our study are that we did not have data on maternal smoking during pregnancy and during the first year of life, and we did not have information on head circumference. Data on gestational age may be subject to random error that would decrease the chance of detecting an association when one could have been detected if the precision of the information was high. These limitations do not detract from the main findings of the study. We could not take into account the possible effects of immunisation on asthma because uptake is close to $100 \%$ in Chile.

\section{Interpretation of the results}

Our contention was that, as the rate of growth in the first year of life is a good summary measure of nutritional status and disease in infancy, if nutritional status is relevant in the aetiology of asthma it would be an ideal measure for assessing an association with respiratory illness. The participants in our study were born when infant mortality in Chile was decreasing but was still high at 50 per $1000 .^{32}$ The weight and length distributions at 1 year showed high nutritional variability but, unexpectedly, the differences in weight and length were modest compared with UK current reference values indicating that malnutrition at that time was only moderate. ${ }^{30}$ It is known that infants with severe malnutrition have low levels of allergic skin test response. ${ }^{33}$ Our findings are concordant in that a greater rate of growth was related to asthma symptoms. It seems that the intervening mechanism is a low birth weight accompanied by a rapid rate of growth. This would indicate that a reasonable nutritional status would be necessary for the development of asthma. We found a statistically insignificant relation between the ratio tertile of length rate/tertile of length at birth and atopy in the same direction and found no relation between the ratio weight and our outcome measures. Based on the rationale of our analyses, an association between the ratio tertile of length rate/tertile of length at birth and asthma symptoms and positive BHR or sensitisation would have been more compelling than results showing a significant association only with asthma symptoms. It is possible that the number of participants with both asthma symptoms and sensitisation or positive BHR was relatively small in comparison with the group in which the presence of asthma symptoms was the only requirement for being part of the group. The effect size of our results lead us to believe that the association between growth gain in infancy and asthma symptoms was sufficiently great to support a meaningful association rather than a fortuitous finding. In our analyses only current smoking behaviour showed a greater size effect in relation to asthma symptoms, and this is convincing because it was also associated with BHR and the $\mathrm{FEV}_{1} / \mathrm{FVC}$ ratio but not with $\mathrm{FEV}_{1}$ (not shown), which is expected in young adults.

We are convinced that the quality of the measurements taken in the paediatric clinic between 1974 and 1978 was reasonably good. We chose only one measurement-the nearest to 1 year-but a series of measurements was available for each child and the clinicians would have detected inconsistencies in the majority of the cases as the main aim of the visit was to check the nutritional progress of the baby.

BMI was assessed at birth with the same intention. A Finnish study reported a U-shaped relationship between ponderal index at birth and atopy, but it was not associated with physician diagnosed asthma. ${ }^{34}$ Our results are the mirror image of the Finnish study as BMI at birth was associated with the two asthma symptoms when considered together, but there was no association with atopy or each asthma symptom separately.

Oddy and Peat ${ }^{35}$ recommended breast feeding as a preventive measure of asthma but other researchers have failed to detect such a difference. ${ }^{16}$ Breast feeding was common in our sample and most mothers attempted to breast feed their children, which is why we could not compare those with and without breast feeding. Our study did not show a beneficial effect of breast feeding in relation to asthma, but we did not have information as to whether the mother was exclusively breast feeding her baby or supplementing it with other food. In a meta-analysis based on longitudinal studies it was reported that exclusive breast feeding was associated with a lower rate of asthma. ${ }^{36}$

In conclusion, in a population suitable for testing the effect of nutritional components at birth and in the first year of life on asthma, we found indications that rapid growth among those with a low length at birth was associated with asthma symptoms. However, such rapid growth was only weakly related to skin sensitisation and was unrelated to BHR and $\mathrm{FEV}_{1}$. Breast feeding and gestational age were unrelated to asthma, atopy, and BHR. This study provides possible clues that nutritional status, especially rapid growth in the first year of life, may be a factor in the aetiology of asthma.

\section{ACKNOWLEDGEMENTS}

The authors thank Dr E Zumelzu, Ms E Moyano, Ms E Bardian and Ms V Alvear for their dedication in collecting data for the project, and 
Dr J Céspedes for training the field workers in the measurements of lung function including methacholine challenge.

\section{Authors' affiliations}

R J Rona, N C Smeeton, Department of Public Health Sciences, King's College London, London, UK

P Bustos, H Amigo, Department of Nutrition, University of Chile, Chile P V Diaz, Institute of Bio-medical Science, University of Chile, Chile

The Wellcome Trust funded the study.

Competing interests: none declared

\section{REFERENCES}

1 Annesi-Maesano I, Moreau D, Strachan D. In utero and perinatal complications preceding asthma. Allergy 2001;56:491-7.

2 Barker DJP, Godfrey KM, Fall C, et al. Relation of birth weight and childhood respiratory infection to adult lung function and death from chronic obstructive airways disease. BMJ 1992:303:671-5.

3 Rona RJ, Gulliford MC, Chinn S. Effects of prematurity and intrauterine growth respiratory health and lung function in childhood. BMJ 1993;306:817-20.

4 Stein CE, Kumaran K, Fall CH, et al. Relation of fetal growth to adult lung function in south India. Thorax 1997;52:895-9.

5 Seidman DS, Laor A, Gale R, et al. Is low birth weight a risk factor for asthma during adolescence? Arch Dis Child 1991;66:584-7.

6 Svanes C, Omenaas E, Heuch JM, et al. Birth characteristics and asthma symptoms in young adults: results from a population-based cohort study in Norway. Eur Respir J 1998;12:1366-70.

7 Mai XM, Gaddlin PO, Nilsson L, et al. Asthma, lung function and allergy in 12-year-old children with very low birth weight: a prospective study. Paediatr Allergy Immunol 2003; 14:184-92.

8 Hagstrom B, Nyberg P, Nilsson PM. Asthma in adult life: is there an association with birth weight? Scand J Primary Care 1998;16:117-20.

9 Shaheen SO, Sterne JA, Tucker JS, et al. Birth weight, childhood lower respiratory tract infection, and adult lung function. Thorax 1998;53:549-53.

10 Leadbitter P, Pearce N, Cheng S, et al. Relationship between fetal growth and the development of asthma and atopy in childhood. Thorax 1999;54:905-10.

11 Demissie K, Ernst $\mathrm{P}$, Joseph $\mathrm{L}$, et al. Birthweight and preterm birth in relation to indicators of childhood asthma. Can Respir J 1997;4:91-7.

12 Kelly YJ, Brabin BJ, Milligan P, et al. Maternal asthma, premature birth, and the risk of respiratory morbidity in schoolchildren in Merseyside. Thorax 1995:50:525-30.

13 Oddy WH, Holt PG, Sly PD, et al. Association between breast feeding and asthma in 6 year old children: findings of a prospective birth cohort study. BMJ 1999;319:815-9

14 Kull I, Wickman M, Lilja G, et al. Breast feeding and allergy diseases in infant-a prospective birth cohort study. Arch Dis Child 2002;87:478-81.

15 Matricardi PM, Rosmini F, Riondino S, et al. Exposure to footborne and orofecal microbes versus airborne viruses in relation to atopy and allergic asthma: epidemiological study. BMJ 2000;320:412-7.
16 Sears MR, Greene JM, Willan AR, et al. Long-term relation between breastfeeding and development of atopy and asthma in children and young adults: a longitudinal study. Lancet 2002;360:901-7.

17 Ponsonby A-L, Couper D, Dwyer T, et al. Relationship between early respiratory illness, family size over time, and the development of asthma and hay fever: a seven year follow up study. Thorax 1999;54:664-9.

18 Pekkanen J, Xu B, Jarvelin MR. Gestational age and occurrence of atopy at age $31-$ a prospective birth cohort in Finland. Clin Exp Allergy 2001;31:95-102.

19 Fergusson DM, Crane J, Beasley R, et al. Perinatal factors and atopic disease in childhood. Clin Exp Allergy 1997;27:1394-401.

20 Godfrey KM, Barker DJP, Osmond C. Disproportionate fetal growth and raised lgE concentration in adult life. Clin Exp Allergy 1994;24:641-8.

21 Jones CA, Holloway JA, Warner JO. Does atopic disease start in foetal life? Allergy 2000;55:2-10.

22 Gregory A, Doull I, Pearce N, et al. The relationship between anthropometric measurements at birth: asthma and atopy in childhood. Clin Exp Allergy 1999;29:330-3.

23 Katz KA, Pocock SJ, Strachan DP. Neonatal head circumference, neonatal weight, and risk of hayfever, asthma and eczema in a large cohort of adolescents from Sheffield, England. Clin Exp Allergy 2003:33:734-45.

24 Anon. Instituto Nacional de Estadísticas, Chile. Available at http:// www.censo2002.cl/menu_superior/cuantos_somos/download/ resultados_preliminares.pdf (accessed 3 April 2004)

25 Anon. Ministerio Nacional de Desarrollo y Planificación, Chile. Available at http://www.mideplan.cl/casen3/comunal/comuna/marcocon.htm (accessed 3 April 2004)

26 Burney P, Luczynska C, Chinn S, et al. The European Community Respiratory Health Survey. Eur Respir J 1994;7:954-60.

27 Chinn S, Jarvis D, Luczynska CM, et al. Measuring atopy in a multi-centre epidemiological study. Eur J Epidemiol 1996;12:155-62.

28 American Thoracic Society. Guidelines for methacholine and exercise challenge testing-1999 (official statement). Am J Respir Crit Care Med 2000;161:309-29.

29 American Thoracic Society. Standardization of spirometry. 1987 update. Am Rev Respir Dis 1987; 136:1285-98.

30 Freeman JV, Cole TJ, Chinn S, et al. Cross sectional stature and weight reference curves for the UK, 1990. Arch Dis Child 1995;73:17-24.

31 Hosmer DW, Lemeshow S. Applied logistic regression, 2nd edn. New York: Wiley, 2000:260-87.

32 Vargas NA, Cerda J. Mortalidad infantil y neonatal en Chile entre 1965 and 1990. Rev Chil Pediatr 1993;64:45-9.

33 Abbassy AA, el-Din MK, Hassan Al, et al. Studies of cell mediated immunity and allergy in protein energy malnutrition. II: Immediate hypersensitivity, J Trop Med Hyg 1974;77:18-21.

34 Xu B, Pekkanen J, Laitinen J, et al. Body built from birth to adulthood and risk of asthma. Eur J Public Health 2002;12:166-70.

35 Oddy WH, Peat JK. Breast feeding, asthma, and atopic disease: an epidemiological review of the literature. J Hum Lactation 2003;19:250-61

36 Gdalevich M, Mimouni D, Mimouni M. Breast-feeding and the risk of bronchial asthma in childhood: a systematic review with meta-analysis of prospective studies. J Pediatr 2001;139:261-6. 